Abditani: Jurnal Pengabdian Masyarakat 2 (2) 48-54

e-ISSN: 2622-4690

p-ISSN: 2622-4682

\title{
MODEL PEMBERDAYAAN MASYARAKAT DALAM PENGELOLAAN KAKAO SECARA TERPADU MENUJU DESA SENTRA KAMPUNG KAKAO MELALUI PROGRAM PENGEMBANGAN DESA MITRA DI KECAMATAN AMPIBABO KABUPATEN PARIGI MOUTONG
}

\author{
Abdul Rahim ${ }^{1 *}$, Gatot Siswo Hutomo ${ }^{1}$, Shahabuddin ${ }^{1}$ dan Farid $^{2}$ \\ ${ }^{1}$ Program Studi Agroteknologi, Fakultas Pertanian Universitas Tadulako, \\ Jln. Soekarno Hatta Km. 9 Palu 94118 Sulawesi Tengah Indonesia \\ ${ }^{2}$ Mahasiswa Program Studi Agroteknologi, Fakultas Pertanian Universitas Tadulako, \\ Jln. Soekarno Hatta Km. 9 Palu 94118 Sulawesi Tengah Indonesia \\ E-mail: a_pahira@yahoo.com
}

\begin{abstract}
ABSTRAK
Provinsi Sulawesi Tengah merupakan penghasil kakao terbesar di Indonesia dan oleh karena itu, kakao ditetapkan sebagai salah satu komoditas unggulan daerah Provinsi Sulawesi Tengah.Program Pengembangan Desa Mitra (PPDM) merupakan Model Pemberdayaan Masyarakat Dalam Pengelolaan Kakao Secara Terpadu Menuju Sentra Kampung Kakao melalui PPDM di Kecamatan Ampibabo Kabupaten Parigi Mourong.PPDM bertujuan untuk meningkatkan pengembangan Usaha Mikro Kecil Menengah (UMKM) mitra untuk peningkatan keberdayaan mitra.Ada dua mitra yang terlibat pada program PPDM adalah Mekar Jaya Kakao Tanampedagi dan Mekar Indah Tanampedagi yang keduanya berada di Desa Tanampedagi Kecamatan Ampibabo Kabupaten Parigi Moutong Propinsi Sulawesi Tengah.Pelaksanaan program akan dilakukan selama 3 (tiga) tahun dengan melibatkan 3 (tiga) dosen yang memiliki kepakaran multidisiplin meliputi ilmu perbenihan, ilmu hama dan penyakit tanaman, teknologi pengolahan hasil pertanian dan ilmu manajemen yang akan menangani semua permasalahan mitra dari aspek pengelolaan perkebunan kakao menuju sentra kampung kakao. Setiap tahun, pelaksanaan kegiatan dilakukan selama 12 bulan dengan rincian 1 bulan persiapan, 10 bulan pelaksanaan kegiatan utama, dan 1 bulan untuk pelaporan. Hasil PPDM pada tahun pertama (2019) tahap $70 \%$ adalah telah dilakukan penyuluhan, pelatihan, praktek dan pendampingan pada kegiatan yang telah disepakati dengan mitra diantaranya teknologi pembibitan tanaman kakao, teknologi pembuatan pupuk organik dengan menggunakan limbah kakao (daun dan kulit kakao), teknologi pembuatan pestisida nabati menggunakan bahan-bahan disekitar perkebunan dan teknologi pemangkasan dan kebersihan perkebunan tanaman kakao, teknologi fermentasi biji kakao. Program kerja PPDM tersebut telah dilaksanakan dan masyarakat petani kakao memiliki keterampilan dalam proses pembibitan, pembuatan bokashi untuk pupuk perkebunan kakao, cara pembuatan pestisida nabati dan cara pemangkasan yang baik untuk meningkatkan produksi tanaman kakao serta cara fermentasi untuk menghasilkan biji kakao yang berkualitas. Masyarakat dan mitra memiliki partisipasi yang tinggi dalam pelaksanaan program karena mereka membutuhkan pengetahuan dan keterampilan yang terkait dengan pengelolaan perkebunan kakao secara menyeluruh.
\end{abstract}

Kata kunci: Pemberdayaan masyarakat, pengelolaan perkebunan kakao secara terpadu, program PPDM, sentra kampung kakao.

\section{Pendahuluan}

Indonesia merupakan negara terbesar ketiga dalam produksi kakao setelah Pantai Gading dan Gana yang berkontribusi sekitar $16 \%$ dari produksi kakao dunia. Pulau Sulawesi berkontribusi $65 \%$ dari produksi kakao nasional dan Provinsi Sulawesi Tengah merupakan penyumbang terbesar sekitar 38\% dari produksi kakao secara nasional (BPS Sulteng, 2015) ${ }^{1}$.Parigi Moutong adalah salah satu kabupaten di wilayah Sulawesi Tengah yang memiliki luasan dan produksi kakao yang paling besar dibandingkan dengan kabupaten lain. Salah satu kecamatan di Kabupaten Parigi Moutong yang memproduksi kakao terbanyak dan warganya umumnya petani kakao adalah Kecamatan Ampibabo. Desa Tanampedagi 
termasuk desa administratif (sesuai UU No.6 Tahun 2014) yang berlokasi di Kecamatan Ampibabo Kabupaten Parigi Moutong Provinsi Sulawesi Tengah yang merupakan salah satu daerah perbukitan atau pegunungan yang cocok dengan perkebunan kakao dan semua penduduknya umumnya bermata pencaharian petani kakao

Menurut BPS Sulteng $(2015)^{1}$ jumlah penduduk Desa Tanampedagi dari 4 dusunadalah 1.456 jiwa yang terdiri dari312 kepala keluarga (KK) dengan penduduk laki-laki sebanyak 730 jiwa dan perempuan 726 jiwa. Jumlah KK yang menjadi petani kakao adalah 303 atau sekitar $97 \%$ bermata pencaharian dari perkebunan kakao, sedangkan sisanya ada yang menjadi buruh tani, penggarap lahan dan PNS serta pelaku usaha bidang pertanian dalam bentuk usaha mikro kecil menengah (UMKM) diantaranya Mekar Indah Tanampedagi dan Mekar Jaya Kakao Tanampedagi, dimana kedua UMKM ini digunakan sebagai mitra dalam program PPDM tahun anggaran 2019-2021. Kakaomerupakan komoditas unggulan di DesaTanampedagi yang berperan penting bagi perekonomian masyrakat. Para petani kakao melakukan budidaya kakao masih berdasarkan pengalaman dan sebagian telah menerapkan teknologi budidaya kakao yang dapat meningkatkan hasil produksi buah kakao. Akhir-akhir ini produksi dan produktivitas kakao di Desa Tanampedagi mulai mengalami penurunan yang sangat berarti bagi petani. Selain tingkat produktivitas yang lebih kecil dibandingkan dengan potensi klon atau bahan tanam yang ada, aspek mutu juga mengalami penurunan. Menurunnya mutu dan daya hasil tersebut dipengaruhi oleh banyak faktor antara lain serangan organisme pengganggu tanaman seperti infeksi penyakit dan serangan hama penggerek buah kakao (PBK), bahan tanam kakao yang diusahakan, penanganan pasca panen, dan sistem usahatani. Teknologi yang tersedia untuk mendukung peningkatan produksi dan pengembangan kakao antara lain bahan tanaman unggul, informasi kesesuaian lahan, teknologi perbanyakan bahan tanaman, teknologi pengendalian hama dan penyakit utama, teknologi sambung samping dan sambung pucuk, teknologi pengolahan hasil dan teknologi pengembangan industri kakao.Teknologi sambung samping telah diadopsi oleh para petani pekebun khususnya untuk merehabilitasi tanaman tua dan tanaman kurang produktif (Rubiyo dan Siswanto, 2013) $)^{2}$.

Pembibitan tanaman kakao yang dilakukan di Desa Tanampedagi umumnya menggunakan biji yang tidak melalui seleksi, tidak mempertimbangkan kualitas media tanam bibit dan keterbatasan dalam hal pemeliharaan bibit sehingga berpengaruh terhadap proses pertumbuhan yang menyebabkan rendahnya produksi buah kakao dan tanaman mudah terserang hama dan penyakit.

Sistem pemeliharaan tanaman perkebunan kakao yang dilakukan oleh petani kakao terlihat belum maksimal seperti pemupukan, perlindungan hama dan penyakit serta pemangkasan. Pemupukan kakao yang dilakukan tidak mengikuti standar pemupukan kakao seperti jenis pupuk, jumlah pupuk dan periode pemupukan. Pemupukan hanya dilakukan dalam jumlah dan frekwensi terbatas, hal ini disebabkan karena para petani mengeluhkan kelangkaan dan harga pupuk sintetik yang mahal ditambah dengan belum adanya sumber pendanaan untuk ketersediaan pupuk. Dalam perlindungan hama dan penyakit pada perkebunan kakao, petani kakao masih menggunakan pestisida sintetik dan belum menggunakan pestisida organik yang berasal dari alam sekitar. Penggunaan pupuk dan pestisida sinteteik akan memperbesar biaya produksi. Petani kakao di Desa Tanampedagi belum mengerti tentang pengolahan limbah kakao (kulit kakao, daun kakao dan pulp) yang dapat dijadikan pupuk bokashi sebagai pengganti pupuk sintetik sehingga biaya produksi dapat ditekan. Beberapa macam produk dapat dihasilkan dari kakao, baik yang berasal dari kulit, daun maupun pulp. Kulit kakao dapat dijadikan kompos, pakan 
ternak, substrat budidaya jamur, ekstraksi theobromin, dan bahan bakar. Demikian halnya petani kakao juga belum memiliki pengetahuan dan kemampuan dalam penggunaan bahan-bahan alami yang ada disekitanya dalam pembuatan pestisida organik.

Pemangkasan kakao yang dilakukan di Tanampedagi belum maksimal, padahal tujuan pemangkasan untuk mengendalikan Penggerek Batang Kakao (PBK), Helopeltis, Penyakit Busuk Buah, vascular streak dieback (VSD), dan Jamur Upas. Selain itu, pemangkasan juga bertujuan untuk merangsang pembuahan dan pertumbuhan tanaman. Menurut Dewi dan Noponen $(2017)^{3}$ bahwa pemangkas dapat membantu menciptakan iklim mikro yang tepat dengan mencegah terlalu rimbunnya atau terlalu lembabnya kebun yang dapat menyebabkan ledakan serangan hama dan penyakit. Menjaga tinggi pohon kakao pada kondisi yang sesuai juga akan mempermudah anda untuk merawat dan memanen kakao. Hal lainnya yang perlu diperhatikan oleh petani kakao di Desa Tanampedagi adalah kebersihan kebun dan fermentasi biji kakao. Tingkat kebersihan kebun kakao di Desa Tanampedagi belum banyak diperhatikan padahal kebun yang bersih memiliki produktivitas yang tinggi karena terhindar dari hama dan penyakit, begitu pula halnya dengan fermentasi biji kakao masih jarang dilakukan.

Dengan demikian program PPDM ini perlu dilakasanakan dengan tujuan untuk membantu masyarakat sasaran dalam meningkatkan pengetahuan dan keterampilan keluarga dan masyarakat dalam memanfaatkan sumber daya lokal secara optimal melalui usaha pengelolaan perkebunan kakao secara terpadu dan berkelanjutan untuk meningkatkan kemampuan dan keterampilan masyarakat dalam pengembangan desa secara terintegrasi menuju sentra kampung kakao.

\section{Metode Pelaksanaan} Kegiatan Prioritas Mitra

Kegiatan mitra yang akan diselesaikan permasalahannnya, adalah pembibitan tanaman kakao, teknologi pembuatan pupuk organik, pembuatan pestisida nabati, pemangkasan tanaman kakao, pengendalian penyakit kakao, teknologi fermentasi dan refermentasi biji kakao. Pelaksanaan kegiatan dilakukan melalui penyuluhan, pelatihan, demonstasi dan pendampingan.

\section{Pelaksanaan}

Kegiatan ini pada dasarnya merupakan kegiatan dalam bentuk pendidikan kepada masyarakatatau mitra (Kartasapoetra, 2006) 9 $^{9}$ Bentuk IPTEKS pendidikan yang dipilih adalah penyuluhan, pelatihan yang dilanjutkan dengan penerapan teknologi dan pendampingan (Sukardiyono, $2000)^{10}$. Untuk itu akan dikembangkan prinsip nilai manfaat yang sesuai dengan pengalaman, praktis, menarik, partisipasi aktif, dan kemitraan (Mardikanto dan Sutami, 2002) ${ }^{11}$. Untuk itu akan dilakukan tiga (3) langkah- langkah solusi atas persoalan yang disepakati bersama berupa kegiatan penyuluhan, pelatihan dan pendampingan. Selain itu juga dilakukan evaluasi secara periodik untuk keterampilan penguasaan teknologi pengelolaan perkebunan kakao mulai hulu sampai ke hilir secara berkelanjutan sehingga pada akhirnya terbentuk masyarakat mandiri yang berbasis tanaman kakao sehingga terbentuk kawasan sentra kampung kakao yang dapat digunakan sebagai tempat pendidikan dan agrowisata.

\section{Hasil dan Pembahasan}

\section{Program PPDM}

\section{a. Cara pembibitan}

Tahapan pembibitan yang dilakukan meliputi (1) pemilihan buah kakao yang masak fisiologis, bentuk dan ukurannya normal dan tidak mengkerut, (2) pengupasan buah kakao, (3) pemilihan biji kakao yang berkualitas kemudian langsung dianginanginkan sampai kadar air $40 \%$, (4) biji 
kakao disemaikan di persemaian pasir atau karung goni, (5) pemidndahan biji yang telah tumbuh ke polibag ukuran $1 \mathrm{~kg}$ yang telah diberi media campuran tanah, pupuk kandang dan pasir dengan perbandingan 1:1:1, (6) penempatan polibag pada bedangan datar, teduh dan diberi atap daun kelapa, (7) pemeliharaan bibit meliputi penyiraman, sanitasi, pemupukan dan penyemprotan dan (8) pemindahan bibit ke lahan perkebunan.

\section{b. Cara pembuatan pupuk organik}

Tahapan pembuatan pupuk organik yaitu (1) kulit kakao segar/lama dikumpulkan, (2) kulit kakao segar dikeringkan sampai kering (3 hari) dengan sinar matahari, sedangkan kulit kakao kering dicincang dengan ukuran kecil-kecil $(2 \mathrm{~cm} \times 2 \mathrm{~cm})$ atau lebih kecil lebih bagus, (3) menyiapkan aktivator pengomposan: $125 \mathrm{~mL}$ EM-4 dilarutkan dengan 10 liter air, (4) pemasangan kotak/plastik/lubang sebagai wadah pengomposan, kotak dapat terbuat dari papan dengan ukuran panjang $2 \mathrm{~m}$ dan lebar $2 \mathrm{~m}$ atau buat lubang dikebun, (5) memasukkan bahan ke dalam cetakan /lubang selapis demi selapis. Tinggi setiap lapisan $\pm 20 \mathrm{~cm}$, kemudian siram tiap lapisan dengan larutan aktivator dan air sebanyak $\pm 250 \mathrm{ml}$. lalu bahan tersebut diinjak-injak agar memadat sambil disiram dengan aktivator pengomposan, (6) setelah kotak/lubang penuh, buka kotak/lubang dan tutup tumpukan kulit buah kakao dengan plastik, (7) kemudian tumpukan tersebut diikat dengan tali dan (8) diinkubasi selama 1,5 bulan untuk buah segar atau 2 minggu untuk kulit buah yang lama, setiap 2-3 hari dilakukan pengamatan. Sedangkan penyuluhan dan pelatihan pembuatan pupuk organik dari daun kakao memalui tahapan yaitu (1) bahan organik (daun kakao, jerami, sampah buah kakao dan dedaunan lainnya) diletakkan dalam lubang/bak, (2) diberi EM4 atau MOL setiap ketebalan/lapisan $10 \mathrm{~cm}$, (3) ditutup rapat lubang dengan terpal, (4) bahan-bahan yang ada di dalam lubang dilakukan pengadukan 2 minggu sekali dan boleh ditambahkan EM-4 atau MOL saat pengadukan, (5) dilakukan penutupan kembali sambil tetap mengotrol temperature dan sekitar 21 hari maka kompos sudah bisa digunakan atau dikemas untuk dikomersialkan. Para petani dapat melakukan pembuatan pupuk dengan teknologi inovasi yang langsung dikebun dengan bahan utama kulit dan daun kakao, sehingga setelah kompos sudah jadi tidak perlu dipindahkan karena pembuatannya dilakukan menggunakan lubang disekitar tanaman kakao.

\section{c. Cara pembuatan pestisida nabati}

Tahapan pembuatan pestisida nabati yaitu (1) menyiapkan bahan-bahan (air, mimba, daun pepaya, daun kakao, daun serai, laos, bawang putih, jerangu dan cabe), (2) semua bahan ditumbuk, (3) bahan yang telah ditumbuk ditambahkan air dan diaduk sampai merata dan (4) difermentasi selama 5 hari. Cara pembuatan pestisida nabati lainnya akan diberikan di lapangan.

\section{d. Cara pemangkasan}

Pemangkasan tanaman kakao dengan berbagai cara yaitu (1) pemangkasan bentuk, (2) pemangkasan pemeliharaan dan (3) pemangkasan produksi. Disamping itu, juga dilakukan penyuluhan dan pelatihan mengenai kebersihan kebun yaitu (1) teknologi pembuatan parit untuk drainase dan (2) pembersihan kebun daun kulit dan daun kakao untuk kemudian dijadikan pupuk organik sekaligus pengendalian hama dan penyakit.

\section{e. Cara fermentasi}

Fermentasi dengan menggunakan kotak atau peti fermentasi. Caranya adalah dengan memasukkan biji kakao ke dalam sebuah kotak yang terbuat dari papan. Ukuran idealnya adalah $60 \mathrm{~cm}$ untuk panjang dan $40 \mathrm{~cm}$ untuk tinggi. Ukuran ini bias menampung kurang lebih $100 \mathrm{~kg}$ biji kakao. Pada hari ke 3, lakukanlah pembalikan agar fermentasi merata dan pada hari ke-6, biji kakao sudah bisa dikeluarkan untuk selanjutnya dijemur sampai kadar air 6-7\%. 


\section{Pembahasan program}

Khalayak sasaran kegiatan PPDM Kepada Masyarakat adalah anggota kelompok Mekar Jaya dan Mekar Indah yang berlokasi di Desa Tanampedagi Kecamatan Ampibabo Kabupaten Parigi Moutong Provinsi Sulawesi Tengah dengan jarak Perguruan Tinggi ke lokasi mitra $89 \mathrm{~km}$ dengan waktu tempuh kurang lebih kurang lebih 100 menit. Kegiatan anggota kelompok Mekar Jaya adalah berkebun kakao dengan status lahan sendiri, pemibibtan dan kompos olahan. Dalam program kegiatan ini difokuskan cara pembibitan yang baik, pemanfaatan limbah tanaman kakao yaitu kulit dan daun kakao sebagai bahan utama pembuatan pupuk bokashi yang selanjutnya pupuk ini dapat digunakan diperkebunan kakao sendiri atau lebih jauh dapat dijadikan lahan bisnis secara komersialisasi, pemangkasan pada kebun demplot dan pembersihan dikebun untuk meningkatkan produksi kakao serta mengurangi menularnya hama dan penyakit. UMKM Mekar Indah bergerak pada proses pengolahan kakao menjadi produk olahan dan yang akan dilakukan pada tahun ini adalah proses fermentasi biji kakao yang kemudian digunakan untuk diversifikasi produk olahan kakao meliputi menjadi pasta, bubuk, minuman cokelat, silverquin dan sebagainya. Kegiatan ini merupakan dilaksanakan oleh tim pengabdi terdiri dari tiga (3) orang dosen yang bergelar akademik S3, satu orang teknisi dan empat (4) orang mahasiswa sebagai supporting kegiatan yang berasal dari Fakultas Pertanian Universitas Tadulako. Pelaksanaan kegiatan dikoordinasikan dengan anggota Mekar Jaya, Mekar Indah dan Kepala Desa Tanampedagi. Metode pendekatan yang digunakan meliputi penyuluhan, pelatihan/demonstrasi proses pembibitan sampai penanaman di kebun demplot, cara pemangkasan dikebun demplot, cara pembuatan bokashi dari kulit dan daun kakao dikebun demplot serta untuk tahapan selanjutnya dilakukan pengendalian hama terpadu dan teknologi fermentasi biji kakao serta juga dilakukan pendampingan, monitoring dan evaluasi. Materi penyuluhan yang disampaikan meliputi adalah pengelolaan perkebunan berbasis manajemen, teknologi pembibitan, teknologi pemangkasan dan pemanfaatan limbah kakao (daun dan kulit). Materi pelatihan yang dilakukan diantaranya teknologi pembibitan, teknologi pemangkasan dan pemanfaatan limbah kakao (daun dan kulit. Hasil pengabdian PPDM tahun anggaran 2019 menambah pengetahuan dan keterampilan anggota kelompok mitra terkait dengan pengelolaan kebun yang baik secara terpadu dan terintegrasi untuk meningkatkan produksi kakao dan meningkatkan kualitas biji kakao, sehingga pada akhirnya meningkatkan kesejahteraan petani kakao khususnya anggota mitra. Pendampingan dilakukan secara periodik dengan tujuan memantau perkembangan pengelolaan kakao di lokasi mitra supaya tetap berkelanjutan. Selain itu juga dilakukan evaluasi secara periodik untuk keterampilan penguasaan dan penerapan yang telah dilatihkan pada mereka dan pola manajemen usaha pertanian sehingga kegiatan ini dapat berkelanjutan dan pada akhirnya terbentuk kelompok Tani Kakao yang mampu melakukan usaha mandiri yang berbasis tanaman kakao Desa Tanampedagi, Kecamatan Ampibabo Kabupaten Parigi Moutong Provinsi Sulawesi Tengah. Untuk keberlanjutan program maka diperlukan peran aktif anggota kelompok tani Mekar Jaya dan Mekar Indah serta peran serta pemerintah dan masyarakat. Di samping itu, program kegiatan ini ditingkatkan dananya yang dilakukan secara kontinu dan mencari sumber pendanaan yang lain diantaranya dari pihak pemerintah dan swasta.

Adapaun dokumentasi kegiatan yang telah dilakukan di Desa Tanampedagi melalui penyuluhan, pelatihan, dan pendampingan pembibitan, pembuatan pupuk kompos, pemupukan dikebun, pemangkasan dan proses fermentasi adalah sebagai berikut: 
e-ISSN: 2622-4690

Abditani: Jurnal Pengabdian Masyarakat 2 (2) 48-54

p-ISSN: 2622-4682
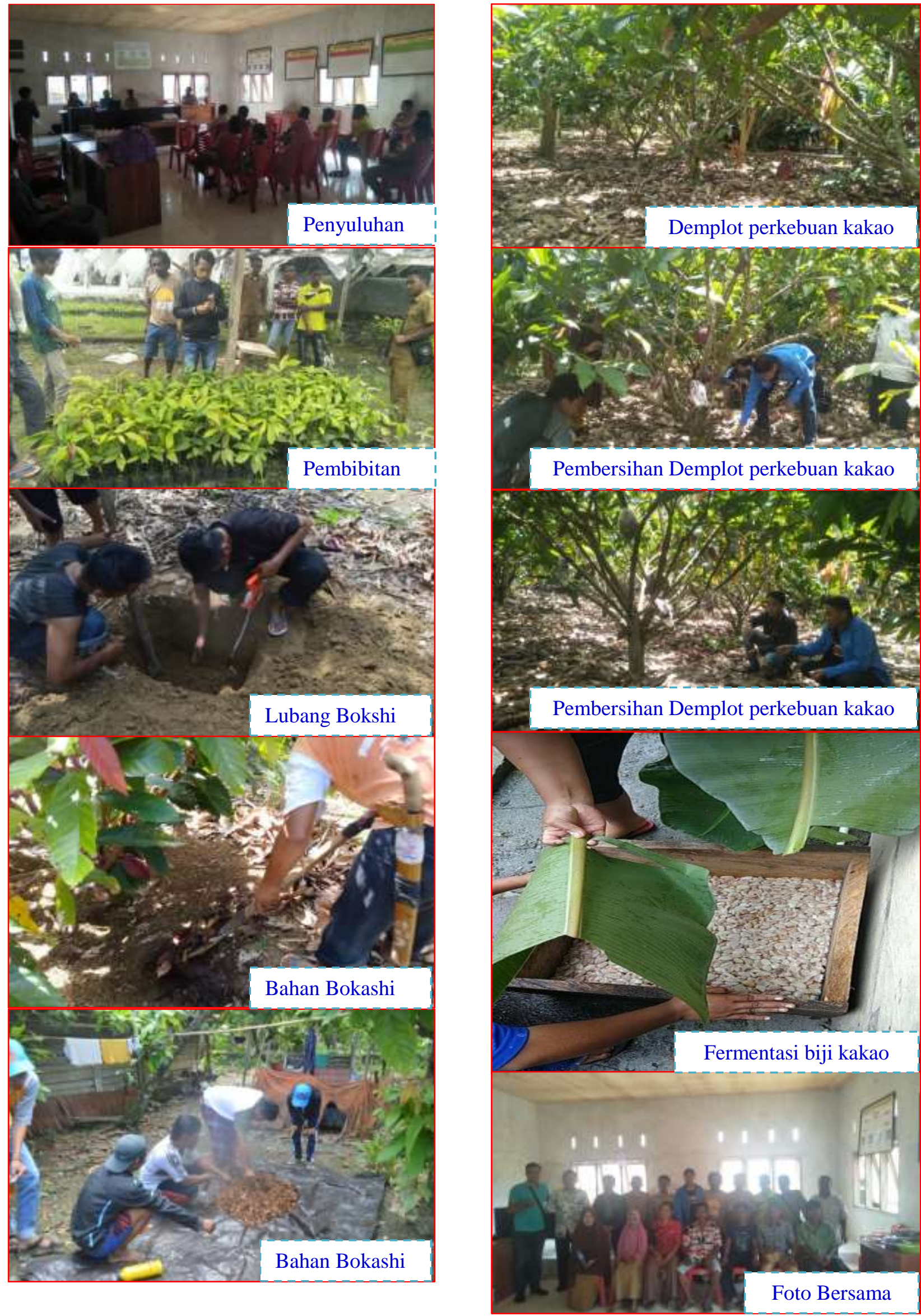


\section{Kesimpulan}

Khalayak sasaran yang terdiri dari anggota mitra telah memiliki kemampuan untuk melakukan pembibitan tanaman kakao yang baik, teknologi pemangkasan dan teknologi pembuatan bokashi dari limbah kakao (daun dan kulit) untuk dapat dipergunankan di lahan kebun kakao. Adanya pengabdian dalam bentuk penyuluhan, pelatihan dan pendampingan meningkatkan kemampuan anggota kelompok dalam melakukan usaha mandiri dan membentuk kawasan industri kecil yang berbasis kakao serta mengetahui manajemen usaha pertanian.

\section{Ucapan Terima Kasih}

Terima kasih disampaikan kepada DRPM Ristekdikti yang telah mendanai keberlangsungan Pengabdian skim PPDM sesuai nomor kontrak: 099/SP2H/PPM/DRPM/2019, ～LPPM
Universitas Tadulako yang telah memfasilitasi pelaksanaan program PPDM, Kepala Desa Tanampedagi dan Mitra.

\section{Daftar Pustaka}

BPS Sulawesi Tengah, 2011. Sulawesi Tengah dalam Angka.BPS Provinsi Sulawesi Tengah.

Dewi dan Noponen. 2017. Buku Saku Pertanian Kakao Tanggap Perubahan Iklim. Rainforest Alliance, Denpasar Bali.

Kartasapoetra, A.G., 2006. Teknologi Penyuluhan Pertanian. Penerbit PT Bina Aksara. Jakarta.

Mardikanto, T., dan Sri Sutarni, 2002. Petunjuk Penyuluhan Pertanian (Teori dan Praktek). Usaha Nasional. Suabaya.

Rubiyo dan Siswanto. 2013. Peningkatan Produksi dan Pengembangan Kakao (Theobroma Cacao L.) Di Indonesia. Buletin RISTRI, 3(1): 33-48.

Sukardiyono, L., 2000. Penyuluhan: Petunjuk bagi Penyuluh Pertanian. Penerbit Erlangga. Jakarta. 